\title{
EFFECTIVITY OF NEW ACETYLCHOLINESTERASE REACTIVATORS IN TREATMENT OF CYCLOSARIN POISONING IN MICE AND RATS
}

\author{
Lucie Bartošová, Kamil Kuča, Gabriela Kunešová
}

\author{
Department of Toxicology, Faculty of Military Health Sciences, Hradec Králové, Czech Republic \\ e-mail: bartosova@pmfhk.cz
}

Received: June 10, 2005; Accepted: September 25, 2005

Key words: Cyclosarin/Oximes/Atropine/ Acute toxicity/ Therapeutic ratio/ Mice/ Rats

\begin{abstract}
The present study was performed to assess and compare a therapeutic efficacy of obidoxime, HI-6, BI-6 and HS-6 administered in equimolar doses and combined with atropine in cyclosarin-poisoned mice and rats. It was demonstrated that all the therapeutic regimens tested, were able to decrease the cyclosarin-induced toxicity significantly - at least 1.5 times. Higher therapeutic ratios, almost three times, were achieved in rats in comparison with mice. The highest therapeutic ratio was achieved for therapeutic regimen consisting of HI-6 and atropine in both mice and rats. Obidoxime was the least effective oxime in the treatment of cyclosarin intoxication. The BI-6 oxime was significantly more efficacious than obidoxime (in both mice and rats) and HS-6 (in rats) but its effectiveness did not reach the efficacy of HI-6.
\end{abstract}

\section{INTRODUCTION}

Organophosphorus (OP) compounds such as soman, sarin or cyclosarin are considered potential warfare agents because of their toxicity. The potential for exposure to $\mathrm{OP}$ compounds exists on the battlefield (e.g., Iran-Iraq war, Desert Storm), in the civilian sector as a threat by a terrorist group (e.g. Tokyo subway incident), or as an accident as part of current demilitarization efforts. New interest in cyclosarin (GF-agent; $O$-cyclohexyl methylphosphonofluoridate) arose shortly after the Gulf War in 1991, when it was recognized that cyclosarin was stockpiled by Iraq ${ }^{1}$.

The acute toxicity of OP compounds in mammals is generally believed to be due to their irreversible inhibition of the enzyme acetylcholinesterase (AChE, EC 3.1.1.7) and subsequent accumulation of the neurotransmitter acetylcholine (ACh) in synapses of the central and peripheral nervous systems and overstimulation of postsynaptic cholinergic receptors ${ }^{2}$. Exposure causes a progression of toxic signs, including hypersecretions, fasciculations, tremor, convulsions, coma, respiratory distress, and death.

The current standard antidotal treatment usually includes a muscarinic $\mathrm{ACh}$ receptor antagonist to block the overstimulation of cholinergic receptors by $\mathrm{ACh}$, and an oxime to reactivate $\mathrm{OP}$-inhibited $\mathrm{AChE}^{3}$. Pralidoxime, obidoxime and HI- 6 are the most widely used representatives of the oximes. These compounds, with quaternary nitrogen that promotes binding in the catalytic site of the $\mathrm{AChE}$, are now a mainstream of treatment for organophosphate exposure. Unfortunately, none from the above mentioned oximes can be regarded as a broad spectrum antidote, because of inability to reactivate $\mathrm{AChE}$ inhibited by all nerve agents ${ }^{4}$. For example, H-oxime HI-6, currently considered as the best known AChE reactivator, is not able to reactivate satisfactorily tabun-inhibited $\mathrm{AChE}^{5}$. Therefore the development of new oximes in an effort to improve the treatment of intoxication with oxime-resistant OP compounds continues. The effective dose of the oxime depends on the nerve agent, the time between poisoning and oxime administration, and other factors ${ }^{6}$.

The present study was performed to assess and compare a therapeutic efficacy of various oximes administered in equimolar doses and combined with atropine in cyclosarin-poisoned mice and rats.

\section{MATERIALS AND METHODS}

\section{Animals}

Female mice, weighing 21-27 g and female rats, weighing 190-250 g (Konarovice, Czech Republic) were kept in air-conditioned room with light from 07:00 to 19:00 h and were allowed to free access to standard chow and tap water. The animals were divided into groups of six animals each. Handling of experimental animals was under the supervision of the Ethics Comittee of the Faculty of Military Health Scineces and the Medical Faculty of Charles University (Hradec Králové, Czech Republic).

\section{Chemicals}

Cyclosarin of $99,9 \%$ purity was obtained from Military Technical Institute in Zemianské Kostolany (Slovak Republic). Its purity was determined by acidimetric titration. The HS-6 oxime (1-(2-hydroxyiminomethylpyridinium)-3-(3-carbamoylpyridinium)-2-oxa-propane dichloride) was a gift of Dr. Stojiljkovic, Serbia and Montenegro. The BI-6 oxime (1-(2-hydroxyiminomethylpyridinium)-4-(4-carbamoylpyridinium)-but-2-ene dibromide) and HI-6 oxime 
(1-(2-hydroxyiminomethylpyridinium)-3-(4-carbamoylpyridinium)-2-oxa-propane dichloride) of at least $98.0 \%$ purity were synthetized earlier in the Department of Toxicology of Faculty of Military Health Scineces in Hradec Králové (Czech Republic). Obidoxime (1,3-bis(4hydroxyiminomethylpyridinium)-2-oxa-propane dibromide) was purchased from Merck (Germany). All other chemicals and drugs of analytical grade were obtained commercially and used without further purification.

\section{Animal experiments}

The oxime therapy combined with atropine was administered intramuscularly (im) 1 min after cyclosarin challenge (im). Dose of each oxime administered for treatment of cyclosarin intoxication was $100 \mu \mathrm{mol} / \mathrm{kg}$ in both mice and rats, atropine dose was $21 \mathrm{mg} / \mathrm{kg}$. The drugs were dissolved in saline and the volume of injection corresponded to $1 \%$ of body weight.

\section{Data analysis}

Cyclosarin-induced toxicity was evaluated by the assessment of $\mathrm{LD}_{50}$ values and their $95 \%$ confidence limits within $24 \mathrm{~h}$ after administration of cyclosarin at five different doses with six mice per dose ${ }^{7}$. The efficacy of tested treatment was expressed as a therapeutic ratio $\left(\mathrm{LD}_{50}\right.$ value of cyclosarin in treated animals/ $\mathrm{LD}_{50}$ value of cyclosarin in non-treated animals). The statistical differences between $\mathrm{LD}_{50}$ values were considered to be significant when $\mathrm{P}<0.05$ using t-test $^{8}$.

\section{RESULTS}

It was demonstrated that all the therapeutic regimens tested, were able to decrease the cyclosarin-induced toxicity significantly - at least 1.5 times (Table 1 ). Higher therapeutic ratios, almost three times, were achieved in rats in comparison with mice. The highest therapeutic ratio was achieved for therapeutic regimen consisting of HI-6 and atropine in both mice and rats. Obidoxime was the least effective oxime in the treatment of cyclosarin intoxication. The BI-6 oxime was significantly more efficacious than obidoxime (in both mice and rats) and HS-6 (in rats) but its effectiveness did not reach the efficacy of HI-6.

\section{DISCUSSION}

When the oximes are administered at the same molar concentration, the acute toxicity of the oximes is not considered, and thus oximes with high acute toxicity might get the intoxication worse. On the other hand, equimolar dosing of oximes is useful when in vitro and in vivo results should be compared. Although cyclosarin is an extremely strong inhibitor of human AChE and butyrylcholinesterase (EC 3.1.1.8) and has obviously an even higher potency than the nerve agent soman $^{9}$, in vivo, cyclosarin is less toxic than soman in several species, including non-human primates ${ }^{10}$, indicating different toxicokinetic behaviour. It was already shown that intoxications with cyclosarin are rather resistant to convential oxime therapy ${ }^{9}$. Since aging should not be the major cause of its refractory property toward oximes (its half aging time is more than $4 \mathrm{~h}$ ), the reason of this phenomenon is worthy of investigation in the future. Previous studies with cyclosarin-poisoned animals suggested a poor efficacy of the marketed oximes obidoxime and pralidoxime ${ }^{11,12}$, whereas the newer oximes HI-6 and HLö 7 proved to be not only very good reactivators of cyclosarin-inhibited $\mathrm{AChE}$ in peripheral and central compartments but they were also effective antidotes in the protection of rats against supralethal poisoning with cyclosarin at doses relevant in humans ${ }^{13}$. Accordingly, in this study it was found that therapeutic regimen consisting of HI-6 and atropine showed the highest therapeutic ratio. In addition, the safety factor of HI-6 is considerably greater than the conventional oximes (pralidoxime or obidoxime). The new oxime BI-6 was nearly as effective as HI-6 against cyclosarin but it does not represent a significant improvement of antidotal treatment of cyclosarin poisoning in comparison with HI-6 (at least in mice). On the other hand, obidoxime, that is presently used in COMBOPEN

Table 1. Therapeutic effect of oximes, administered at equimolar dose in combination with atropine $(21 \mathrm{mg} / \mathrm{kg})$ $1 \mathrm{~min}$ after cyclosarin challenge, on the LD50 of cyclosarin in mice and rats

\begin{tabular}{|c|c|c|c|}
\hline Treatment & Animal & $\begin{array}{c}\mathrm{Ld} 50(\mu \mathrm{g} / \mathrm{kg}) \pm 95 \% \\
\text { confidence limits }\end{array}$ & $\begin{array}{c}\text { Therapeutic } \\
\text { ratio }\end{array}$ \\
\hline \multirow{2}{*}{-} & Mice & $\begin{array}{c}279.0 \\
(254.9-305.3) \\
\end{array}$ & - \\
\hline & Rats & $\begin{array}{c}152.0 \\
(120.0-168.0)\end{array}$ & - \\
\hline \multirow{2}{*}{$\begin{array}{l}\text { Obidoxime } \\
+ \text { atropine }\end{array}$} & Mice & $\begin{array}{c}432.7 \\
(415.1-451.1) \\
\end{array}$ & 1.55 \\
\hline & Rats & $\begin{array}{c}735.0 \\
(702.0-770.0)\end{array}$ & 4.8 \\
\hline \multirow{2}{*}{$\begin{array}{l}\text { HI- } 6+ \\
\text { atropine }\end{array}$} & Mice & $\begin{array}{c}895.5 \\
(769.5-1042.2) \\
\end{array}$ & $3.21 *$ \\
\hline & Rats & $>2000$ & $>13.2 \#$ \\
\hline \multirow{2}{*}{$\begin{array}{l}\text { BI- } 6+ \\
\text { atropine }\end{array}$} & Mice & $\begin{array}{c}605.6 \\
(559.8-655.0) \\
\end{array}$ & $2.17^{*}$ \\
\hline & Rats & $>2000$ & $>13.2 \#$ \\
\hline \multirow{2}{*}{$\begin{array}{l}\mathrm{HI}-6+ \\
\text { atropine }\end{array}$} & Mice & $\begin{array}{c}589.1 \\
(557.5-622.6) \\
\end{array}$ & $2.11 *$ \\
\hline & Rats & $\begin{array}{c}848.0 \\
(789.0-897.0)\end{array}$ & $5.6 \#$ \\
\hline
\end{tabular}

*significantly different from the obidoxime-treated group at the level of $\mathrm{P}<0.05$

\# significantly different from the obidoxime-treated group at the level of $\mathrm{P}<0.05$ 
autoinjector, is not able to protect cyclosarin-poisoned mice and rats such effectively as other oximes tested.

In conclusion, HI-6 still seems to be the most suitable oxime for treatment of cyclosarin poisoning. HI-6 was not only the most effective oxime in cyclosarin poisoning but also its low acute toxicity, in comparison with other oximes, enables to administer relatively high doses for treatment. However, since antidotes in most countries do not use HI-6 in the regimen due to the poor stability of this compound, medical protection against cyclosarin poisoning would remain a problem.

\section{ACKNOWLEDGEMENT}

The authors express their appreciation to Mrs. J. Uhlirova for her excellent technical assistance and to Mr. V. Blaha for his help with the statistical evaluation. The study was supported by the Grant of Ministry of Defense of Czech Republic no. ONVLAJEP20031.

\section{REFERENCES}

1. Gee J. (1992) Iraqui declaration of chemical weapons: how much did they have and and what was it? Fourth International Symposium on Protection Against Chemical Warfare Agents, June 8-12, Stockholm, Sweden.

2. Marrs TC. (1993) Organophosphate poisoning. Pharmacol Ther $58,51-66$.
3. Bajgar J. (2004) Organophosphates/nerve agent poisoning mechanism of action, diagnosis, prophylaxis, and treatment. Adv Clin Chem 38, 151-216.

4. Worek F, Reiter G, Eyer P, Szinicz L. (2002) Reactivation kinetics of acetylcholinesterase from different species inhibited by highly toxic organophosphates. Arch Toxicol 76, 523-529.

5. Kuča K, Bielavský J, Cabal J, Kassa J. (2003) Synthesis of a new reactivator of tabun inhibited acetylcholinesterase. Bioorg Med Chem Lett 13, 3545-3547.

6. Sidell FR. Nerve agents. In: R. Zajtchuk and R.F. Bellamy (Eds.), Medical aspects of chemical and biological warfare, Washington: Office of The Surgeon General at TMM Publications 1997. p. 129179.

7. Tallarida R, Murray R. Manual of pharmacological calculation with computer programs. Second ed., New York: Springer-Verlag 1987. p. $145-160$.

8. Roth Z, Josifko M, Trcka V. Statistical methods in experimental medicine. Praha: Statni zdravotnicke nakladatelstvi 1962. p. 405 in Czech.

9. Worek F, Eyer P, Szinicz L. (1998) Inhibition, reactivation and aging kinetics of cyclohexylmethylphosphonofluoridate-inhibited human cholinesterases. Arch Toxicol 72, 580-587.

10. Koplovitz I, Gresham VC, Dochterman LW, Kaminskis A, Stewart JR. (1992) Evaluation of the toxicity, pathology and treatment of cyclohexylmethylphosphonofluoridate (CMPF) poisoning in rhesus monkeys. Arch Toxicol 66, 622-628.

11. Sevelova L, Kuca K, Krejcova-Kunesova G. (2005) Antidotal treatment of GF-agent intoxication in mice with bispyridinium oximes. Toxicology 207, 1-6.

12. Ševelová L, Krejčová G, Kuča K, Vachek J. (2004) Therapeutic efficacy of different antidotal mixtures against poisoning with GFagent in mice. Acta Medica (Hradec Králové) 47, 249-251.

13. Kassa J, Cabal J, Bajgar J, Szinicz L. (1997) The choice: HI-6, pralidoxime or obidoxime against nerve agents? ASA Newslett. 97, $16-18$. 